\title{
MODA TRANSPORTASI TRADISIONAL JAWA (Traditional Transportation Equipment in Java)
}

\section{Lilyk Eka Suranny}

Kantor Penelitian, Pengembangan Iptek Kab.Wonogiri Jl. Brigjend Katamso No. 2, Wonogiri e-mail: lilik_fd@yahoo.com

\section{INFO ARTIKEL}

\section{Histori artikel}

Diterima: 27 Juli 2016

Direvisi: 21 Agustus 2016

Disetujui: 14 Oktober 2016

\section{Keywords: \\ traditional transportation, pedicab, \\ wagon, \\ gerobag, \\ onthel bicycle}

\section{Kata kunci:}

moda transportasi tradisional, becak,

delman,

gerobag,

sepeda onthel

\begin{abstract}
The transportation technologies develop more rapidly along with the development of science and technology. One of consequences is the traditional transportation being abandoned by the community. Therefore, it needs cultural presenvation efforts, especially in traditional transportation because it is a high historical value for indonesia. This article describe some kind of traditional transportation modes in Java. It also described the role of society in the era of globalization. Data was collected using observation, interviews and literature study. This study used a qualitative descriptive method. Based on the research of traditional modes of transportation used by the Java community is pedicab, wagon, gerobag and onthel bicycle. Traditional modes of transportation have a role namely the role of social, cultural, economic and environmental.
\end{abstract}

\section{ABSTRAK}

Perkembangan teknologi transportasi semakin pesat sejalan dengan perkembangan ilmu pengetahuan dan teknologi. Salah satu dampaknya adalah moda transportasi tradisional semakin ditinggalkan oleh masyarakat. Oleh karena itu diperlukan upaya pelestarian budaya khususnya pada alat transportasi tradisional karena memiliki nilai historis yang tinggi bagi bangsa Indonesia. Tulisan ini menguraikan beberapa jenis moda transportasi tradisional di Jawa. Selain itu juga dijelaskan mengenai peranannya dalam masyarakat di tengah era globalisasi. Teknik pengumpulan data dilakukan melalui observasi, wawancara dan studi kepustakaan. Penelitian ini menggunakan metode deskriptif kualitatif. Berdasarkan hasil penelitian moda transportasi tradisional yang digunakan oleh masyarakat Jawa yakni becak, delman, gerobag dan sepeda onthel. Moda transportasi tradisional memiliki peranan yaitu peran sosial, budaya, ekonomi dan lingkungan.

\section{PENDAHULUAN}

Transportasi memiliki peranan penting dalam kehidupan berbangsa dan bernegara. Berdasarkan UndangUndang no 22 tahun 2009 tentang Lalu Lintas dan Angkutan Jalan, bahwa lalu lintas dan angkutan jalan mempunyai peran strategis dalam mendukung pembangunan dan integrasi nasional sebagai bagian dari upaya memajukan kesejahteraan umum sebagaimana diamanatkan oleh Undang-Undang Dasar Negara Republik Indonesia tahun 1945. Alat transportasi digunakan oleh manusia untuk memperlancar aktivitas dalam kehidupannya.
Menurut Bowersox (1981: 7) transportasi merupakan pemindahan barang atau orang dari satu tempat ke tempat lainnya, dimana produk dipindahkan ke tempat tujuan yang dibutuhkan. Sedangkan Transportasi menurut Salim (1993:5) adalah sarana bagi manusia untuk memindahkan sesuatu baik orang atau benda dari satu tempat ketempat lain, dengan ataupun tanpa mempergunakan alat bantu. Alat bantu tersebut dapat berupa tenaga manusia, binatang, alam ataupun benda lain dengan mempergunakan mesin ataupun tidak bermesin. Oleh karena itu moda transportasi tidak dapat dipisahkan dalam kehidupan 
manusia karena keberadaannya dapat mendukung kelangsungan kegiatan ekonomi, sosial budaya, politik, maupun pertahanan keamanan.

Modernisasi telah merambah pada berbagai bidang dalam kehidupan termasuk dibidang transportasi. Perkembangan ilmu pengetahuan dan teknologi mampu membuat inovasi moda transportasi yang semakin canggih dari waktu kewaktu. Alat transportasi modern dibuat dengan tenaga mesin sehingga dapat meningkatkan efisiensi dalam mencapai tujuan kegiatan pemindahan orang/barang dari suatu tempat ketempat lain menggunakan alat transportasi. Sebelum adanya alat transportasi modern seperti saat ini, pada jaman dulu nenek moyang kita telah dapat membuat alat transportasi tradisional yang sederhana dengan digerakkan oleh tenaga manusia ataupun hewan.

Pada jaman paleolitik manusia prasejarah hidup secara berpindahpindah (nomaden) untuk memenuhi kebutuhan hidupnya. Mereka melakukan perjalanan dari satu tempat ke tempat lainnya untuk mencari makananmaupuntempattinggaldengan berjalan kaki. Pada jaman neolitik manusia prasejarah telah mengenal bercocok tanam dan hidup menetap. Pada masa ini manusia prasejarah mulai membuat wadah dan peralatan lainnya untuk menunjang pemenuhan kebutuhannya, salah satunya dengan membuat alat transportasi tradisional. Alat transportasi yang dibuat sangat sederhana dengan bahan baku yang digunakan berasal dari alam sekitar. Kadang mereka melakukan perjalanan cukup jauh dan waktu yang lama untuk mencapai tempat tujuan sehingga muncul inisiasi menggunakan bantuan hewan ternak untuk membantu dalam membawa barang atau manusia (Soekmono, 1973:45).

Ada beberapa jenis moda (alat) transportasi yang ada saat ini yaitu transportasi darat, laut dan udara. Moda transportasi darat merupakan alat transportasi yang pada dasarnya berfungsi sebagai penunjang mobilitas masyarakat di jalur darat (Warpani, 1990: 30). Transportasi darat dapat diklasifikasikan berdasarkan kriteria geografis fisik dan geografis administratif. Moda transportasi darat berdasarkan kriteria geografis fisik terdiri dari moda transportasi jalan rel, perairan daratan, moda transportasi khusus dari pipa dan kabel, serta moda transportasi jalan raya. Sedangkan berdasarkan kriteria geografis administratif, moda transportasi darat terdiri dari transportasi dalam kota, transportasi desa, transportasi antar kota dalam propinsi, transportasi antar kota antar propinsi, dan transportasi lintas batas antar negara /internasional (Miro, 2012: 17 ).

\section{Perkembangan transportasi} darat tersebut berkembang seiring dengan perkembangan pola pikir manusia dibidang teknologi. Awalnya transportasi hanya menggunakan tenaga manusia ataupun dengan memanfaatkan bantuan hewan. Pada tahap ini muncul penggunaan gerobag, pedati, cikar sebagai sarana pengangkut manusia atau barang dengan tenaga hewan sebagai penggeraknya. Alat transportasi darat tersebut kemudian berkembang setelah ditemukannya mesin sehingga banyak moda transportasi darat yang digerakkan menggunakan mesin, seperti bus, mobil, dan kereta api.

Beberapa penelitian mengenai moda transportasi tradisional yaitu penelitian Yuni Astuti tahun 2010, yang berjudul "Eksistensi Angkutan Becak 
dalam Perkembangan Transportasi di Yogyakarta". Kesimpulan yang diperoleh dari penelitian tersebutadalah becak di daerah Yogyakarta masih digunakan oleh masyarakat sebagai sarana transportasi alternatif meskipun telah banyak transportasi modern saat ini. Penelitian lain yaitu oleh Rismawati tahun 2011 mengenai "Eksistensi Alat Transportasi Delman (Keretek) Terhadap Kehidupan Kusir Delman di Kecamatan Majalaya, Kabupaten Bandung". Penelitian tersebut bertujuan untuk mengetahui faktorfaktor apa saja yang mempengaruhi eksistensi alat transportasi delman terhadap kehidupan penduduk (kusir) di Kecamatan Majalaya, Kabupaten Bandung dan juga untuk mengetahui kondisi sosial ekonomi kusir delman (keretek) di Kecamatan Majalaya, Kabupaten Bandung. Metode yang digunakan untuk mengungkapkan permasalahan adalah metode survei. Teknik penelitian yang digunakan adalah observasi, wawancara, studi dokumentasi, dan studi literatur. Kesimpulan penelitian ini adalah bahwa yang mempengaruhi eksistensi alat transportasi delman/keretek adalah lokasi trayek yang khusus dilalui delman, pendidikan yang rendah sehingga memaksa mereka untuk tetap menekuni pekerjaan sebagai kusir delman/keretek, selain itu eksistensi keretek itu sendiri di pengaruhi oleh kondisi jalan yang masih berbatu dan semi aspal. Hasil penelitian ini juga menunjukkan kehidupan/kondisi sosial ekonomi kusir delman yaitu dilihat dari pendapatannya sudah bisa memenuhi kebutuhan sehari-hari dan mampu memenuhi kebutuhan seperti kepemilikan fasilitas kehidupannya cukup baik terutama sarana komunikasi yang dimiliki setiap kusir.

Pada saat ini keberadaan moda trasportasi tradisional mulai terpinggirkan dengan adanya berbagai jenis moda trasportasi modern. Moda transportasi tradisional dianggap kuno, ketinggalan jaman dan lambat. Kebanyakan masyarakat di Pulau Jawa sudah banyak yang beralih pada moda transportasi modern. Namun dibalik itu semua ternyata dapat kita ambil berbagai manfaat dari penggunaan alat transportasi tradisional ini. Pertama, ramah lingkungan sehingga tidak menimbulkan polusi udara karena tanpa menggunakan bahan bakar. Kedua, lebih ekonomis baik dari segi biaya pembuatannya maupun pengoperasiannya. Ketiga, sebagai sarana pelestarian budaya nenek moyang yang unik dan tidak ternilai harganya. Oleh karena itu perlu adanya upaya pelestarian alat transportasi tradisional agar generasi yang akan datang dapat menikmati ataupun sekedar mengetahui beberapa moda transportasi tradisional sebagai kekayaan budaya bangsa Indonesia. Permasalahan yang akan diuraikan dalam penelitian ini adalah apa saja moda transportasi tradisional yang digunakan oleh masyarakat di Pulau Jawa dan bagaimana peranannya dalam kehidupan masyarakat saat ini? Sehingga tujuan dari penelitian ini adalah mengetahui jenis alat trasportasi tradisional terutama yang berkembang di Pulau Jawa sebagai salah satu wujud pelestarisan budaya. Selanjutnya juga akan diuraikan mengenai peranannya dalam kehidupan masyarakat saat ini.

Penelitian ini merupakan penelitian deskriptif melalui pendekatan kualitatif. Menurut Nawawi (1983:64), metode penelitian deskriptif memiliki 2 ciri pokok yaitu memusatkan perhatian pada masalah yang diteliti dan menggambarkan fakta-fakta tentang masalah yang sedang diteliti diiringi dengan interpretasi rasional. Bagdan dan Taylor dalam Moleong (2003:3), 
menyatakan bahwa penelitian kualitatif merupakan penelitian yang menghasilkan data deskriptif berupa kata-kata tertulis atau lisan dari orang-orang dan perilaku yang diamati. Teknik pengumpulan data dilakukan melalui pengamatan dalam masyarakat (observasi), wawancara pada beberapa informan, dokumentasi dan studi kepustakaan. Pengamatan dilakukan pada beberapa daerah terutama di pulau Jawa yang masih menggunakan moda transportasi tradisional. Informan dalam penelitian ini dipilih menggunakan teknik snowball sampling dengan bantuan key-informan pada pemilik alat transportasi tradisional dan beberapa orang yang masih menggunakan moda transportasi tradisional tersebut. Teknik analisis data yang digunakan dalam penelitian ini adalah analisis deskriptif kualitatif, yaitu menganalisis, mendeskripsikan, menggambarkan dan menguraikan peristiwa yang terjadi yang diperoleh dari pada saat penelitian dilakukan. Temuan-temuan data dan fakta dari hasil pengamatan mengenai beberapa jenis alat trasportasi tradisional terutama yang berkembang di Pulau Jawa dan juga peranannya pada masyarakat saat ini. Tahapan analisis data mengacu pada tahapan analisis data menurut Miles dan Hiberman dalam Sugiono (2013: 91) yaitu reduksi data, penyajian data, penarikan kesimpulan.

\section{PEMBAHASAN}

\section{Alat Transportasi Tradisional}

Pulau Jawa merupakan pusat perkembangan peradaban nusantara sejak abad ke-4, jalur perhubungan yang berkembang adalah jalur darat. Hal ini terjadi karena awal kehidupan manusia prasejarah berada di daratan. Pulau Jawa merupakan wilayah yang paling padat penduduknya di
Indonesia (http://bayualfian.blogspot. com/2011/11/pengantar-transportasi. html). Semakin banyak penduduknya maka kebutuhan sarana untuk saling berinteraksi antar sesama juga semakin banyak, sehingga kebutuhan sarana transportasi juga meningkat. Dari tahun ke tahun alat transportasi semakin berkembang mulai dari alat transportasitradisionalyang digerakkan dengan tenaga hewan ataupun manusia sampai alat transportasi yang digerakkan dengan mesin. Dengan adanya alat transportasi modern ini, seyogyanya kita sebagai generasi penerus bangsa senantiasa selalu menjaga kelestarian alat transportasi tradisional tersebut agar tidak punah. Berdasarkan hasil penelitian berikut akan diuraikan beberapa jenis alat transportasi tradisional yang ada di Pulau Jawa antara lain:

\section{Becak}

Becak merupakan moda
transportasi keberadaanya tidak hanya di Pulau Jawa tetapi juga terdapat di beberapa wilayah Indonesia bahkan sampai luar negeri. Sebagai moda transportasi tradisional, becak digerakkan dengan menggunakan tenaga manusia. Becak (betjak) berasal dari berasal dari Tiongkok, bee yang berarti kuda dan tja yang berarti gerobag, sehingga betjak memiliki arti kuda gerobag atau kereta kuda. Becak masuk ke Indonesia untuk pertama kali pada awal abad ke-20 untuk keperluan pedagang Tionghoa mengangkut barang. Pada tahun 1937 yang tertulis dalam Star Weekly, becak dikenal dengan nama roda tiga dan kata betjak/betja/beetja baru digunakan pada 1940 ketika becak mulai digunakan sebagai kendaraan umum. Keaneragaman bentuk dari keunikan becak ini yang harus dijaga, dan menjadi daya tarik tersendiri 
untuk wisatawan, terlebih lagi di Indonesia memiliki keanekaragaman bentuk becak di setiap daerahnya (Suwarmintarta, 2008: 3).

Di Indonesia terdapat dua jenis becak yakni becak dengan pengemudi belakang dan becak dengan pengemudi samping. Becak dengan pengemudi di belakang umumnya banyak ditemukan di Pulau Jawa sedangkan becak dengan pengemudi di samping umumnya terdapat di Pulau Sumatera. Becak tradisional memiliki tiga roda, dua roda dibagian depan dan 1 roda dibagian belakang. Dua roda depan dihubungkan dengan sebuah poros tetap. Pengemudi becak duduk di atas roda bagian belakang yang diberi tempat duduk (saddle) dan menggenjot pedal sehingga roda belakang akan berputar sama dengan prinsip sepeda kayuh. Sedangkan penumpang duduk diatas kursi penumpang yang berada di depan. Jumlah normal penumpang yang dapat diangkut adalah dua orang, tetapi kadang ada juga yang membawa lebih dari jumlah normalnya. Rangka yang membentuk badan becak terbuat dari besi dan ada pula yang terbuat dari kayu. Pada badan becak tersebut bagian atasnya ditutup terpal untuk melindungi penumpang dari panas dan hujan. Adapula yang memberi tambahan terpal lipat yang terbuat dari plastik bening serta dapat digulung, fungsinya untukmelindungipenumpang ataupun barang bawaan pada saat hujan sehingga bagian depan becak tidak basah. Rem yang digunakan pada becakpun juga sederhana, yaitu menggunakan sebuah tongkat yang diletakkan diantara kursi pengemudi dan tempat duduk penumpang. Selain sebagai alat transportasi penumpang, becak juga digunakan sebagai alat angkut barang.

Becak tersebut selain digunakan sebagai alat transportasi tradisional juga digunakan sebagai becak wisata, misalnya saja di Yogyakarta, Solo dan sekitarnya. Di wilayah tersebut keberadaan becak mampu bersaing dengan kendaraan modern lainnya karena ternyata memiliki daya tarik sendiri bagi penggunanya. Becak di Yogyakarta sangat mendukung promosi wisata karena alat transportasi tradisional ini merupakan salah satu daya tarik wisatawan domestik maupun mancanegara. Kartodirdjo (1981: 58) menyatakan bahwa becak di Yogyakarta mulai muncul sebelum Perang Dunia II sekitar tahun 1940 an, saat itu becak difungsikan sebagai alat transportasi baik sebagai alat transportasi antar karesidenan maupun tempat kerja di kota. Karena banyak yang menggunakannya maka biaya operasinyapun lebih murah dan tentunya lebih cepat daripada berjalan kaki.

Becak, pariwisata, dan Yogyakarta merupakan perpaduan yang membentuk suatu ikon destinasi pariwisata yang unik dan tidak dimiliki olehdaerahlain(Suwarminarta, 2008:3). Para wisatawan sangat antusias untuk menikmati pemandangan di kota Gudeg (sebutan untuk Yogyakarta) dengan mengendarai becak. Ada jalur-jalur khusus yang dilalui becak wisata, misalnya di Malioboro. Jalur tersebut erat kaitannya dengan keberadaannya yang dekat dengan obyek wisata, penginapan (hotel), maupun dekat dengan pusat oleholeh khas Yogyakarta. Selain dapat menikmati wisata belanja, wisatawan juga dapat menikmati ramainya jalan Malioboro dengan berkeliling menggunakan becak. Pengemudi becak wisata tersebut juga bertindak sebagai guide (pemandu wisata) karena dalam perjalanannya mereka mengkomunikasikan beberapa 
keindahan objek wisata di daerah setempat. Oleh karena itu diharapkan pemerintah daerah dapat memberikan pelatihan sebagai pemandu wisata kepada pemilik ataupun pengemudi becak. Hal ini akan dapat mendorong peningkatan ekonomi bagi para pengemudi ataupun pemilik becak karena ongkos yang didapatkan dari becak wisata akan lebih besar dibandingkan jika menjadi tukang becak murni (melayani penumpang biasa). Di Solo, becak masih digunakan sebagai alternatif angkutan umum jarak pendek selain juga digunakan sebagai becak wisata. Berdasarkan wawancara dengan salah satu penumpang becak, mengatakan bahwa "Saya sering menggunakan becak sebagai angkutan jarak pendek misalnya dari pasar ke rumah karena tarifnya yang ekonomis dan menyenangkan sambil menikmati perjalanan" (Wawancara dengan lbu Supriyanti, 24 Juli 2014).

\section{Masyarakat}

utamanya

kelas menengah kebawah masih menggunakan becak sebagai alternatif angutan umum untuk rute pendek karena tarifnya murah dan dirasa nyaman. Kondisi masyarakat menengah kebawah yang memiliki tingkat ekonomi yang masih kurang sehingga keberadaan becak akan sangat diminati sebagai alat transportasi jarak pendek karena biayanya yang terjangkau dan ramah lingkungan. Pada saat menaiki becak terjadi relasi dan interaksi antara pengemudi becak dan penumpangnya yang kemudian menjadikan suatu keakraban dan saling percaya. Banyak pedagang yang mempercayakan pengambilan barang dagangan di pasar pada pengemudi becak yang menjadi langganannya. Becak mudah diperoleh pada beberapa wilayah yang strategis misalnya dekat pasar, pinggir jalan raya, ataupun dekat area perbelanjaan. Biasanya para pengemudi becak mangkal di tempat-tempat tersebut untuk mencari penumpang/barang tumpangan. Keberadaan becak saat ini utamanya di perkotaan memang dapat menimbulkan dampak positif dan negatif. Bagi sebagian orang dengan adanya becak akan dapat membantu memperlancar aktivitas/mobilitas masyarakat. Selain itu juga ramah lingkungan karena tidak menimbulkan polusi udara. Namun disisi lain juga keberadaan becak tersebut dapat menimbulkan kemacetan yang mengganggu arus lalu lintas. Berbagai kebijakan telah diambil pemerintah untuk mengatasi masalah tersebut misalnya saja dengan pembatasan jumlah operasional becak, menentukan wilayah operasional becak, bahkan

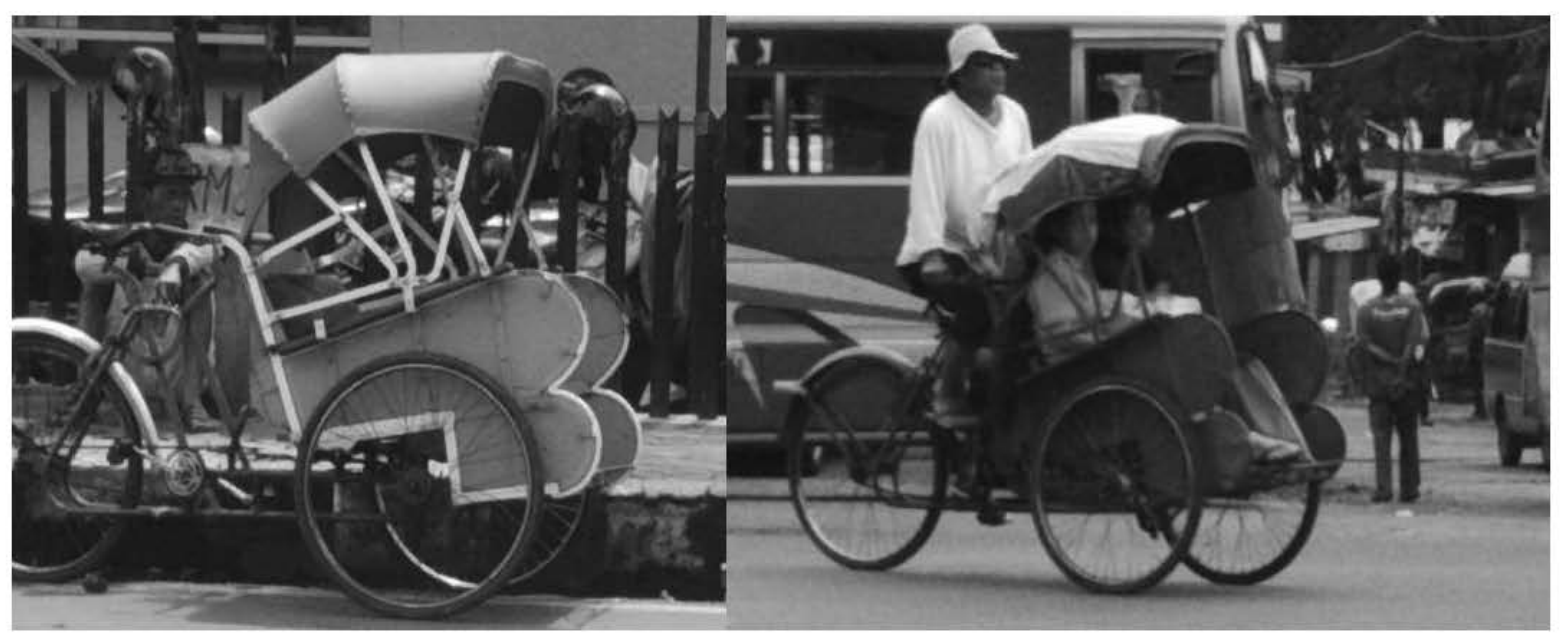

Gambar 1. Becak Jawa (dokumentasi Lilyk) 
dengan penertiban. Hal ini dilakukan pemerintah untuk mengatasi kemacetan yang diakibatkan oleh becak namun tetap masih memikirkan keberadaan becak sebagai penopang ekonomi bagi sebagian masyarakat. Keberadaan becak saat ini sebagai kendaraan umum bagi sebagian masyarakat menengah kebawah sangat berbanding terbalik dengan keberadaan becak dimasa lalu sebagai kendaraan para bangsawan dan dianggap sebagai barang mewah, kemudian berangsur-angsur menjadi kendaraan umum yang digunakan oleh masyarakat.

\section{Delman}

Delman atau kereta kuda merupakan alat transportasi tradisional yang menggunakan roda berjumlah dua sampai empat roda yang ditarik menggunakan tenaga kuda. Alat transportasi ini ditemukan oleh seorang litografer dan insinyur pada masa Hindia Belanda yang bernama Charles Theodore Deeleman. Oleh karena itu alat transportasi ini dinamakan delman, yang diambil dari nama penemunya. Pada masa penjajahan Belanda, delman merupakan alat transportasi antar kota sebelum kereta dan trem masuk ke Indonesia. Jumlah kuda sebagai penarik delman ini bervariasi dari satu sampai dua kuda. Kuda dipilih sebagai penarik delman karena dinilai memiliki tenaga yang besar. $\mathrm{Di}$ beberapa daerah alat transportasi yang berupa kereta kuda (delman) ini diberi penamaan yang berbeda-beda, namun pada dasarnya sama. Perbedaan itu hanya terdapat pada jumlah roda yang digunakan dan jumlah kuda yang menariknya. Pada jaman dulu orang Belanda menyebut delman sebagai "dos a dos" yang dalam Bahasa Perancis mengandung arti "punggung bertemu punggung" atau kereta yang posisi duduk penumpangnya saling memunggungi. Orang-orang pribumi Batavia terbiasa menyebutnya dengan nama "sado"(http://akhmadfauzi. weebly.com/teknologi-nasional).

Di beberapa daerah di Indonesia delman dikenal dengan nama yang berbeda-beda. Dalam bahasa Sunda delman dikenal dengan sebutan Kahar dan Keretek. Di Sumatera delman sering disebut dengan bendi. Pada masa Hindia Belanda, bendi biasa digunakan oleh para pejabat negara, saudagar kaya dan kerabatnya. Bendi memiliki dua roda yang ditarik oleh satu atau dua kuda. Delman juga dikenal dengan nama dokar. Penamaan dokar berasal dari orang-orang pribumi pada jaman penjajahan. Para penjajah sering mengatakan "Dog car" pada kendaraan yang digunakan untuk berburu anjing. Kendaraan yang dipakai sejenis dengan delman, sehingga orang pribumi ada yang menyebutnya dengan nama dokar. Dokar ini terdapat pada beberapa daerah di Pulau Jawa dengan modifikasi bentuk namun pada pola (dasar) yang sama. Dokar memiliki dua roda dan ditarik oleh satu ekor kuda.

Di Pulau Jawa delman juga dikenal dengan sebutan andong. Andong terkenal sebagai warisan budaya Jawa yang keberadaannya sampai sekarang dapat ditemukan di beberapa daerah, antara lain Yogyakarta, Solo dan daerah di sekitarnya. Andong memiliki empat roda dan ditarik oleh satu atau dua kuda. Sejarah mengenai andong ini dimulai dari berdirinya keraton Hadiningrat, dimana raja-raja Mataram atau Yogyakarta dulu menggunakan andong sebagai kendaraan. Pada awal abad ke 19 sampai abad 20 yang pada saat itu dipimpin oleh Sultan Hamengku Buwono VII, andong hanya 
boleh digunakan oleh para bangsawan dan kerabatnya. Sedangkan pada saat dipimpin oleh Sultan Hamengku Buwono VIII, andong sudah dapat digunakan oleh masyarakat umum terutama para pedagang untuk menggangkut hasil dagangannya ke beberapa daerah. Andong yang dipakai oleh raja-raja beserta keluarganya dinamakan kereta kencana.

Eksistensi/keberadaan andong saat ini selain sebagai alat transportasi umum juga digunakan sebagai destinasi wisata untuk menarik wisatawan, misalnya saja di Yogyakarta. Hal ini seperti dikemukakan oleh kusir andong, Pak Joyo (wawancara tanggal 14 Juli 2014). Beliau mengatakan "Biasanya saya narik andong ini untuk mengantar orang/barang ke suatu tempat, misalnya ke pasar ada juga turis yang ingin diantar keliling di sepanjang jalan Malioboro, biasanya saya mangkal di sekitar Jalan Malioboro." Keberadaan andong di Yogyakarta ini juga dipertegas oleh salah satu penumpang andong, Pak Anton (wawancara tanggal 14 Juli 2014), yang mengatakan "Saya sering naik andong untuk pergi ke suatu tempat biasanya ke pasar karena tarifnya murah dan tidak perlu antri, kadang kalau sudah langganan bisa sewaktuwaktu dipanggil." Pernyataan yang dikemukakan tersebut, memperkuat bahwa andong yang merupakan alat transportasi tradisional ini masih sering digunakan oleh masyarakat di Yogyakarta untuk bepergian, misalnya saja ke pasar ataupun sebagai penarik wisatawan. Faktor-faktor yang menjadi penunjang sehingga masyarakat masih menggunakan andong adalah tarifnya tergolong murah dan mereka merasa nyaman karena interaksi yang ramah dari kusirnya sehingga tumbuh ikatan emosional diantara penumpang dan kusir. Hal ini membuat penumpang akan menggunakan jasanya kembali baik untuk mengantar bepergian ataupun sekedar mengantar barang. Keunikan andong wisata di Yogyakarta adalah pada bagian depan andong wisata tercantum nomor andong ada yang ditulis dengan huruf Jawa. Kusir (pengemudi) biasanya memakai pakaian lurik (sorjan) dan blangkon. Inilah yang menjadi cirikhas andong wisata dikota Yogyakarta. Andong wisata biasanya banyak ditemukan di daerah obyek wisata dan sekitarnya.

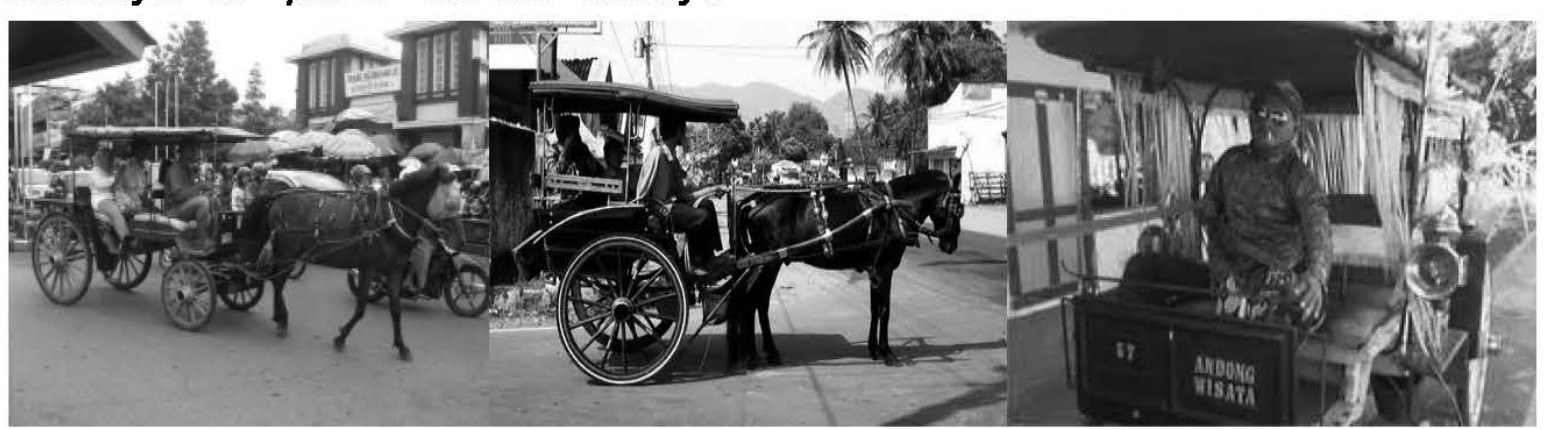

Gambar 2. Delman/andong/dokar/sado/bendi

(Sumber: http://www.gongsol.com/index.php/indonesian-transportations-what-you-need-to-know/)

\section{Pedati (Gerobag)}

Pedati atau gerobak adalah alat transportasi tradisional yang memiliki satu sampai empat buah roda, terbuat dari kayu dan bagian atapnya dibuat dari anyaman bambu ataupun bahan lain yang fungsinya untuk melindungi penumpang/barang yang diangkut. Beberapa gerobag yang digunakan sebagai alat angkut barang yang ditarik oleh manusia dibuat tanpa 
menggunakan atap. Gerobag dapat ditarik oleh hewan seperti sapi, kerbau atau dapat pula ditarik oleh manusia. Gerobag telah disebut dalam berbagai literatur sejak abad ke-2 SM. Kitab suci India Rgveda menulis bahwa pria dan wanita bagaikan dua roda dari gerobag (http://id.wikibooks.org/wiki/Moda Transportasi/Moda_Transportasi_ Jalan.).

Gerobag di Indonesia ini telah ada sejak jaman Kerajaan Majapahit. Pada saat pemerintahan Raja Hayam Wuruk gerobag sapi digunakan sebagai alat transportasi pengangkut barang. Pada saat itu gerobag sapi merupakan kendaraan yang tergolong mewah karena tidak semua golongan mampu untuk membeli gerobag sekaligus sapi sebagai penariknya. Gerobag sapi mengalami kejayaaan pada masa kolonial Hindia Belanda tepatnya pada masa tanam paksa. Gerobag sapi digunakan untuk menggangkut hasil bumi dari wilayah pedalaman Indonesia ke pelabuhan untuk dibawa ke Belanda. Kejayaan gerobag sapi ini didukung dengan pembangunan jalan-jalan penghubung dari pedalaman ke pelabuhan. Sejalan dengan perkembangan jaman dan pengembangan teknologi saat ini, keberadaan gerobag sapi semakin terpinggirkan. Gerobag sapi ini tergantikan dengan kendaraan yang dijalankan dengan tenaga mesin bukan lagi menggunakan tenaga hewan ataupun manusia (http://twilightjava. blogspot.com/2013/11/raja-jalananyang-tersingkir-dari.html.).

Dengan perkembangan teknologi, manusia mampu membuatinovasi yang terinspirasi dari gerobag tradisional yaitu pembuatan troli belanja yang diberi roda kecil pada bagian bawahnya untuk mempermudah membawa barang. Biasanya troli belanja banyak ditemukan di supermarket atau di pasar-pasar modern. Untuk mengatasi kepunahan gerobag sapi sebagai salah satu alat transportasi tradisional yang pernah berjaya pada jaman dulu tersebut, perlu dilakukan upaya-upaya pelestarian budaya yang menjadi warisan nenek moyang. Salah satunya yakni dengan diadakannya festival Gerobag Sapi yang saat ini telah dikembangkan di daerah Sleman dan Yogyakarta. Selain untuk melestarikan budaya, festival Gerabag Sapi ini di lakukan untuk menyebarluaskan dan mengenalkan kendaraan tradisional kepada generasi penerus bangsa. Harapannya gerobag sapi dapat dijadikan ikon budaya dan wisata di Yogyakarta seperti andong dan becak. Bila dulu gerobag sapi digunakan sebagai alat angkut hasil bumi, saat ini gerobag sapi akan dikembangkan sebagai ikon kendaraan wisata yang unik dan mengandung nilai budaya dan nilai historis masyarakat Jawa.

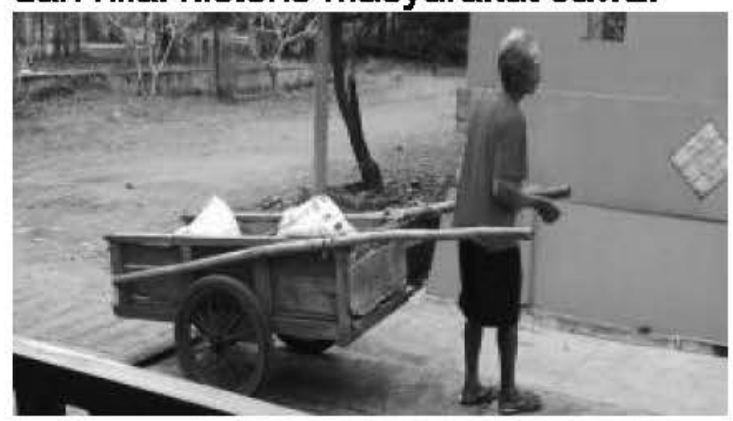

Gambar 3. Gerobag sebagai alat angkut barang (dokumentasi Lilyk)

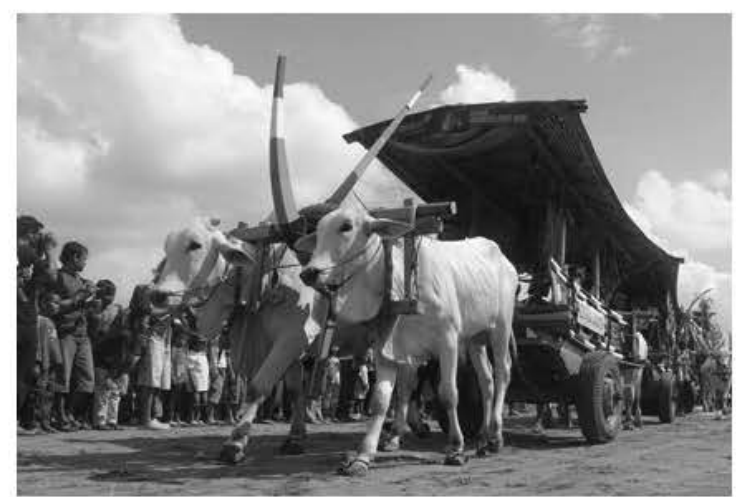

Gambar 4. Festival Gerobag Sapi di Yogyakarta (Sumber: http:/www.jogjapages. com/berbagai-lomba-ramaikan-festivalgerobak-sapi-2014/) 


\section{Sepeda Onthel}

Sepedamerupakan alat transportasi yang sederhana dan digerakkan oleh tenaga manusia dengan dikayuh. Sepeda onthel juga dikenal dengan sebutan sepeda unta atau sepeda kebo, sepeda jengki, kumbang, sundung, sepeda baheula, dan masih banyak julukan yang diberikan oleh masyarakat Indonesia pada sepeda lawas/kuno ini. Kata jengki berasal dari kata jingke (bahasa Betawi, artinya berjinjit), jadi ketika naik kita harus berjingke karena tinggi, sedangkan kata onthel berasal dari bahasa Jawa artinya dikayuh karena untuk menggerakkannya perlu dikayuh. Sepeda onthel umumnya memiliki ukuran ban 28 inchi dan rangka berasal dari besi, bentuknya unik desainnya dibuat tinggi dengan bentuk kemudi yang unik. Sepeda ontel dibawa ke Indonesia pada masa kolonial Belanda.

Sepeda onthel tersebut digunakan sebagai alat transportasi manusia ataupun juga barang. Pada jaman dulu masyarakat sering menggunakannya sebagai alat angkut hasil bumi, rumput untuk hewan ternak ataupun barangbarang lainnya. Seiring dengan perkembangan teknologi pemakaian sepeda onthel tersebut semakin terpinggirkan. Masyarakat lebih memilih menggunakan alat transportasi menggunakan mesin seperti sepeda motor. Kehidupan makin terpacu yang mempengaruhi kebutuhan itu menciptakan gaya hidup melalui alat transportasi yang lebih bersifat pragmatisme yang menyebabkan sepeda onthel makin terpinggirkan keberadaannya (Junius, 2010: 83).

Sepeda digunakan sebagai alat untuk bersenang-senang, melakukan petualangan dan menjaga kesehatan. Disamping itu juga merupakan sarana transportasi yang hemat (Ismunandar,
1996:1). Di daerah pedesaan ada beberapa yang masih menggunakan sepeda onthe/sebagai alat transportasi. Berdasarkan penuturan dari bapak Jatmiko sepeda onthel miliknya masih digunakan untuk pergi ke sawah dan membawa peralatan kerjanya. Menurut beliau sepeda onthel tersebut merupakan warisan dari orangtuanya.

Berikut kutipan wawancara dengan Bapak Jatmiko "Saya kalau ke sawah naik onthel dengan membawa cangkul dan sabit, onthel ini warisan dari bapak saya dulu". Pernyataan yang dikemukan tersebut menunjukkan bahwa sepeda onthel oleh sebagian masyarakat di pedesaan masih digunakan sebagai alat transportasi untuk mempermudah pekerjaan yang dilakukan, baik untuk memindahkan orang ataupun barang. Sebagian dari mereka menggunakan sepeda onthel sebagai alat angkut hasil panen untuk dijual ke pasar ataupun sekedar untuk diangkut ke rumah. Para pemiliknya selalu berusaha untuk merawat dan menjaganya karena barang tersebut sudah langka dan memiliki sejarah sebagai warisan dari orang tua ataupun leluhurnya. Penggunaan sepeda onthel ini juga dilatar belakangi karena masyarakat umumnya di pedesaan merasa mendapatkan keuntungan yang lebih ekonomis tanpa harus mengeluarkan bahan bakar untuk menggerakkannya.

Disisi lain, keberadaan sepeda onthel sangat jarang sekali terlihat ataupun dimiliki oleh masyarakat $\mathrm{di}$ perkotaan. Kepemilikan sepeda onthel di perkotaan biasanya bagi mereka yang memiliki hobi sebagai kolektor sepeda onthel. Para kolektor ini bahkan memiliki lebih dari satu buah karena mereka memandang sepeda lawas tersebut memiliki keunikan yang tinggi sehingga menjadikannya 
sebagai barang kesayangan. Saat ini keberadaannya yang semakin langka membuat harga sepeda onthel ini semakin mahal. Namun bagi mereka yang gemar mengkoleksi sepeda onthel bahkan akan selalu berusaha menambah koleksinya. Penampilan sepeda onthel yang terkesan tua dan kebanyakan digunakan oleh orang tua tersebut, membuat anak muda kurang tertarik untuk menggunakan sepeda tersebut. Namun di sisi lain sepeda onthel ini merupakan alat transportasi tradisional yang ramah lingkungan sekaligus menyehatkan.

Sepeda onthel semakin terpinggirkan di masyarakat, namun beberapa orang tergerak untuk membentuk komunitas komunitas pecinta sepeda onthel tersebut. Komunitas ini merupakan wadah bagi para pecinta sepeda onthel sebagai wujud melestarikan dan menghargai warisan sejarah. Mereka para pecinta onthel ini membentuk suatu komunitas sepeda tua indonesia (KOSTI) yang tersebar di beberapa daerah di Indonesia. Untuk di Yogyakarta komunitas pecinta onthe/ dinamai Jogja Onthel Community (JOC). Hadirnya komunitas onthelis tersebut bertujuan untuk menanamkan pemahaman tentang adanya perkembangan masyarakat dari masa lalu hingga masa kini dan menumbuhkan tali silaturahmi sesama anggotanya terhadap sepeda onthel yang menjadi simbul kesederhanaan di Yogyakarta (Junius, 2010: 84).

Pada kenyataannya membangun komunitas sepeda memerlukan waktu. Membangun suatu komunitas sebenarnya bisa dilakukan dalam kurun waktu kurang dari setahun, namun khusus untuk komunitas sepeda onthel ini promosi sering menghadapi tantangan pada masalah psikologi masa yang masih terlihat sepeda onthel sebagai kendaraan yang minim gengsi, disamping faktor infrastruktur dan sebagainya. Beberapa faktor yang menentukan kenapa komunitas sepeda begitu cepat tumbuh. Pertama maraknya kepedulian lingkungan. Kedua yaitu pentingnya gaya hidup sehat bagi sebagian besar masyarakat urban, Ketiga mekarnya semangat para urban untuk saling bersosialisasi (Wiyancoko, 2010: 84).

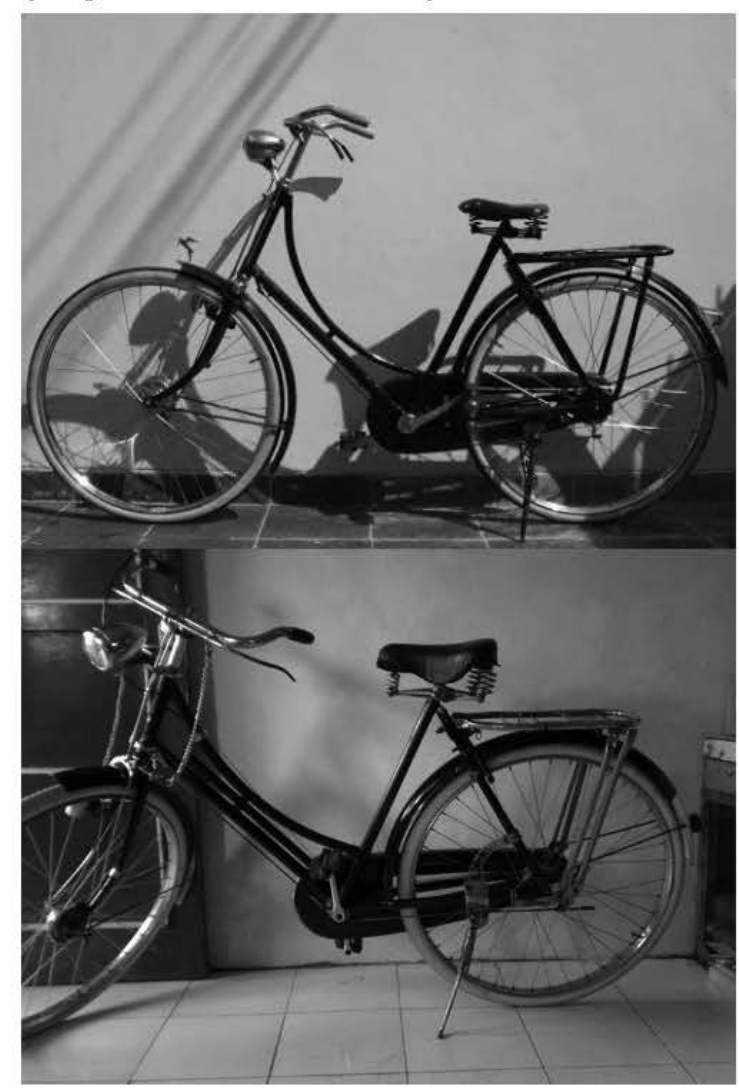

Gambar 5. Gambar sepeda onthel (dokumentasi Lilyk)

\section{Peranan Moda Transportasi Tradisional Bagi Masyarakat Modern}

Moda transportasi bermanfaat bagi masyarakat dalam menjalani kehidupan sehari-hari. Masyarakat dunia telah mengenal sarana transportasi sejak lama. Berawal dari rasa keingintahuan manusia terhadap lingkungannya dan mencari tempat yang dapat dihuni untuk memenuhi segala keinginannya, sehingga manusia menciptakan alat 
transportasi. Peranan alat transportasi tradisional dalam masyarakat dapat berupa peran sosial, peran ekonomi, peran lingkungan dan budaya.

Peran sosial alat transportasi tradisionaladalahsebagaimoda/sarana untuk memindahkan orang/barang dari suatu tempat ke daerah tujuan. Moda transportasi tradisional ini dapat membantu manusia untuk berinteraksi dengan manusia lainnya baik secara individual ataupun berkelompok. Pada jaman dulu pemilik dan pengguna moda transportasi tradisional misalnya andong/dokar merupakan orangorang dari kelas bangsawan yang memiliki status sosial yang tinggi dalam masyarakat. Namun saat ini alat transportasi tradisional tersebut dapat digunakan oleh semua kalangan masyarakat tanpa memandang status sosial mereka. Moda transportasi tradisional digunakan oleh sebagian masyarakat sebagai angkutan umum, misalnya saja becak di beberapa daerah di Jawa. Munculnya kendaraan umum tersebut karena adanya hubungan sosial, terbentuknya sistem masyarakat yang mempunyai tujuan demi keberlangsungan dan kebersamaan, serta kesejahteraan bersama sehingga memicu adanya kendaraan bersama (umum). Penggunaan kendaraan modern sebagai kendaraan pribadi dapat memunculkan sifat individualistik dan materialistik yang dapat memisahkan manusia dari masyarakatnya. Sifat yang demikian hendaknya dapat kita hindari karena pada dasarnya manusia adalah makhluk sosial yang saling ketergantungan satu dengan yang lainnya.

Peran dari sisi budaya pada moda transportasi tradisional yaitu penggunaan moda transportasi tradisional oleh masyarakat modern merupakan salah satu bentuk pelestarian budaya bangsa yang adiluhung. Beberapa moda transportasi tradisional digunakan sebagai daya tarik wisata budaya di Indonesia. Misalnya saja di Yogyakarta dan Surakarta, delman ataupun becak banyak digunakan sebagai kendaraan wisata untuk menarik wisatawan baik dalam maupun luar negeri. Para wisatawan ternyata sangat menikmati perjalanan menggunakan moda transportasi tradisional yang dianggap unik dan bernilai budaya tinggi. Bagi para seniman, mereka memandang bahwa alat transportasi tradisional merupakan benda seni yang bernilai harganya tanpa mengesampingkan fungsi utamanya sebagai alat transportasi. Misalnya saja becak yang diberi grafiti dan lukisan akan nampak memiliki nilai seni yang tinggi meskipun hanya berupa alat transportasi tradisional yang sederhana.

Peran moda transportasi tadisional pada sisi ekonomi adalah moda transportasi tradisional ini masih digunakan oleh beberapa masyarakat di Jawa sebagai mata pencaharian sehari-hari. Hal tersebut dapat kita lihat dalam masyarakat, misalnya para kusir delman/andong ataupun juga tukang becak yang masih mengandalkan moda transportasi tradisional untuk menopang perekonomiannya. Moda transportasi tradisional tersebut merupakan milik sendiri ataupun hanya menyewa pada orang lain. Di beberapa daerah moda transportasi tradisional masih dijadikan sebagai alternatif pilihan bagi sebagian masyarakat sehingga mereka memanfaatkan keadaan tersebut untuk mencari rejeki. Dengan adanya moda transportasi tradisional ini dapat mengurangi jumlah pengangguran di masyarakat, sehingga transportasi tradisional juga berperan sebagai penggerak perekonomian 
masyarakat. Hal ini terlihat pada perputaran/mobilisasi barang/manusia ini dapat terjadi karena adanya moda transportasi.

Peran moda transportasi tradisional dari sisi lingkungan yaitu moda transportasi tradisional merupakan sarana transportasi yang ramah lingkungan karena tidak menggunakan bahan bakar, hanya menggunakan tenaga manusia/hewan untuk menggerakkannya. Kendaraan modern seperti halnya mobil atau sepeda motor menggunakan bahan bakar yang dapat menimbulkan polusi udara. Polusi udara tersebut dapat menyebabkan gangguan kesehatan pada manusia. Selain itu moda transportasi tradisional tidak menggunakan mesin sehingga tidak akan menimbulkan kebisingan di lingkungan sekitarnya. Delman/andong ataupun gerobag sapi merupakan moda transportasi tradisional yang menggunakan bantuan hewan (kuda/ sapi) sebagai penggeraknya. Kadang yang menjadi masalah bagi lingkungan adalah adanya kotoran hewan yang mencemari lingkungan sekitar. Namun mereka para pengemudi delman/ andong tersebut memberi kantong kotoran sehingga kotoran hewan tidak akan berceceran di jalan.

Alattransportasi tradisional maupun alat transportasi modern memiliki sisi kelebihan dan kekurangan masingmasing. Alat transportasi tradisional dinilai lambat dan kurang efisien serta banyak menimbulkan kemacetan lalu lintas. Namun alat transportasi tradisional ini juga memiliki sisi positif yang banyak menguntungkan seperti yang telah diuraikan diatas, baik dari peran sosial, budaya, ekonomi maupun lingkungan. Penggunaan alat transportasi modern jika tidak berhati-hati dapat menimbulkan kecelakaan lalu lintas.
Kelemahan penggunaan masing-masing alat transportasi seyogyanya kita koreksi bersama agar penggunaan teknologi dapat menunjang kelestarian dan keberlanjutan lingkungan sekitarnya.

\section{PENUTUP}

Pada era globalisasi ilmu pengetahuan dan teknologi semakin berkembang ke arah modernisasi di segala bidang. Bidang transportasi tak luput dari modernisasi akibat globalisasi baik transportasi darat, laut maupun udara yang semakin memudahkan pergerakan manusia maupun barang. Perkembangan di bidang transportasi ini sangat penting bagi kemajuan bangsa. Transportasi akan menyediakan akses bagi masyarakat untuk memenuhi kebutuhan hidupnya baik di daerah perkotaan maupun pedesaan. Teknologi transportasi yang berkembang saat ini akan mempermudah manusia dalam memenuhi kebutuhan hidupnya sehingga dapat meningkatkan kehidupan sosial ekonomi masyarakat. Perkembangan di bidang transportasi seyogyanya tidak melupakan warisan budaya dari nenek moyang yang berupa alat transportasi tradisional. Namun saat ini keberadaannya sudah semakin jarang ditemukan pada masyarakat.

\begin{tabular}{|c|}
\hline $\begin{array}{l}\text { Beberapa alat } \begin{array}{r}\text { transportasi } \\
\text { tradisional masih } \\
\text { keberadaannya di wilayah Jawa }\end{array} \\
\text { antara lain andong, becak, gerobag } \\
\text { dan sepeda onthel. Andong dan becak } \\
\text { banyak ditemui di tempat-tempat } \\
\text { wisata karena digunakan sebagai } \\
\text { penarik wisatawan baik dalam maupun } \\
\text { luar negeri. Keunikan keduanya dapat } \\
\text { menjadi perhatian para wisatawan } \\
\text { karena tidak dapat dinikmati di daerah } \\
\text { tempat tinggalnya. Gerobag oleh }\end{array}$ \\
\hline
\end{tabular}


alat angkut barang. Sedangkan sepeda onthel masih digunakan oleh masyarakat meskipun sudah jarang ditemukan, bahkan para pecinta sepeda onthel membentuk komunitas sepeda onthel untuk menjaga kelestarian sepeda onthel sebagai alat transportasi tradisional yang dianggap unik. Nilai budaya dan historis dari penemuan berbagai alat transportasi tradisional ini mampu untuk menginspirasi pembuatan alat transportasi modern. Oleh karena itu keberadaan alat transportasi tradisional ini sepatutnya untuk dipertahankan sebagai warisan budaya bangsa Indonesia yang tak ternilai harganya. Terlebih anak muda sebagai generasi penerus bangsa Indonesia harus ikut melestarikan kebudayaan yang ada di Indonesia ini termasuk alat transportasi tradisional. Selain itu juga memperkenalkan keseluruh dunia bahwa Indonesia memiliki warisan sejarah yang sampai sekarang masih bertahan. 


\section{DAFTAR PUSTAKA}

Astuti, Yuni. 2010. "Eksistensi Angkutan Becak dalam Perkembangan Transportasi di Yogyakarta". Jurnal Ampta. HIm 1-8.

Bowersox, C. 1981. Introduction to Transportation. New York: Macmillan Publising Co, Inc. Hal 7.

Ismunandar. 1996. Olahraga Balap Sepeda. Semarang: Dahara Prize.HIm 1.

Junius, Ronald . 2010. "Peran Jogja Onthel Community Dalam Melestarikan Sepeda Onthel di Yogyakarta". Skripsi Mahasiswa Jurusan Sosiologi Fakultas IImu Sosial Dan Politik Universitas Sebelas Maret Surakarta. HIm 83- 84.

Kartodirdjo, Sartono. 1981. The Pedicab in Yogyakarta: A Study of Law Cost Transportation and Proverty Problems. Yogyakarta: Gadjah Mada University Press.

Miro, Fidel. 2012. Pengantar Sistem Transportasi. Jakarta: Erlangga. HIm 17.

Moleong, Lexy.2003. "Metode Penelitian Kualitatif". Bandung: Remaja Rosdakarya. HIm 3.

Nawawi, H. 1983. Metode Penelitian Sosial. Yogyakarta: Gajah Mada University Press, HIm 64.

Rismawati, Lina. 2011. "Eksistensi Alat Transportasi Delman (Keretek) Terhadap Kehidupan Kusir Delman di Kecamatan Majalaya Kabupaten Bandung". Skripsi FPIPS.

Salim, Abbas. 1993. Manajemen Transportasi. Jakarta: PT. Grafindo Persada.

Soekmono, R.1973. Pengantar Sejarah Kebudayaan Indonesia .Jakarta: Yayasan Kanisius.

Sugiono. 2013. Metode Penelitian Pendidikan (Pendekatan Kuantitatif Kualitatif dan Research Design). Bandung: Alfabeta.

Wiyancoko, Dudy. 2010. Desain Sepeda Indonesia. Jakarta: Kepustakaan Populer Gramedia.HIm 84. 